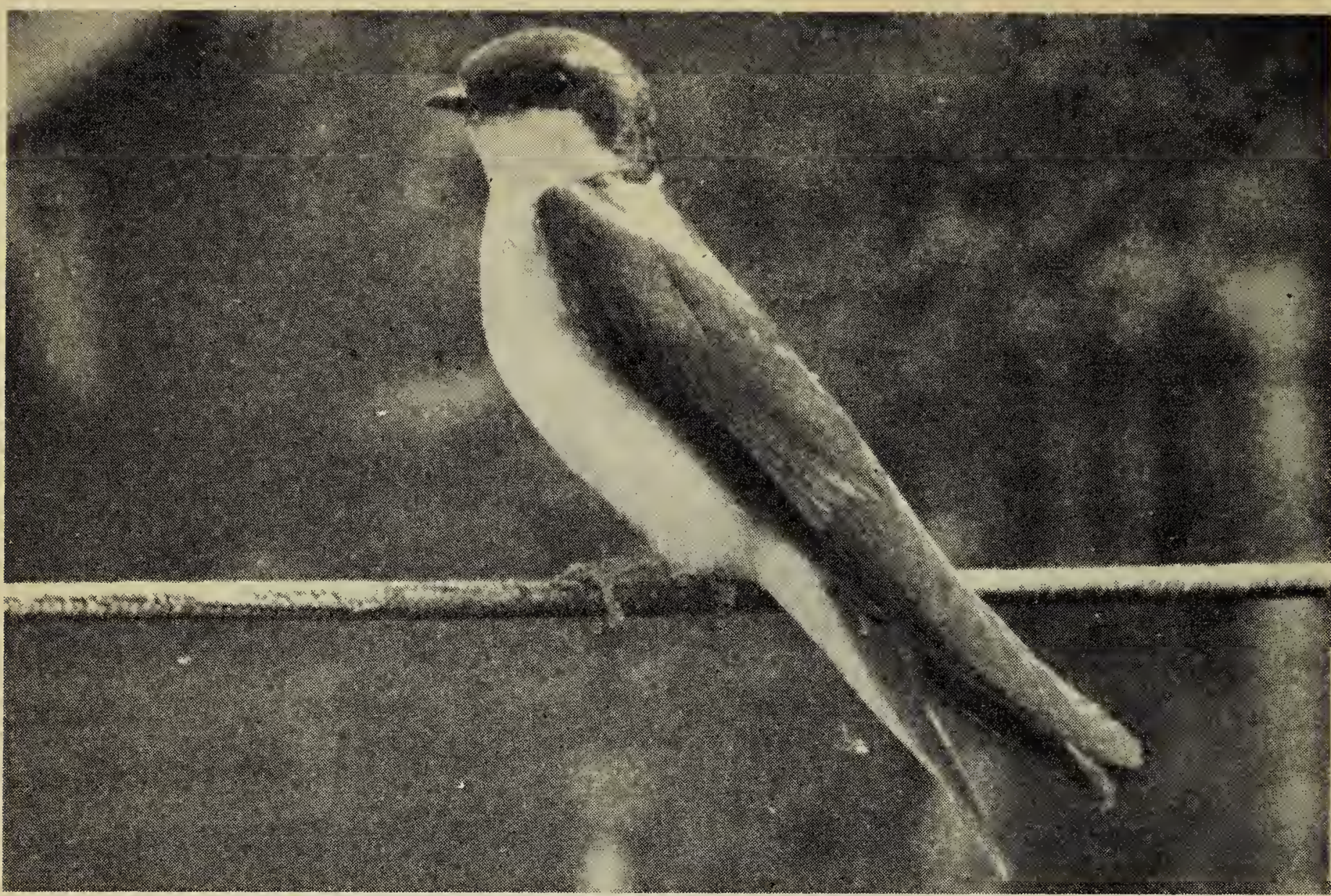

Photo by $R$. W. Fyte

nesting box which already contained a great deal of House Sparrow nesting material. The Tree Swallows immediately left this area.

Another nest, containing seven Tree Swallow eggs, was visited on June 6. Revisiting this nest on June 10, I caught a female House Sparrow in possession and to my surprise the Tree Swallow eggs were replaced by two House Sparrow eggs.

The fact that half of the eight Tree Swallow nests of which I kept records in 1960 were destroyed by House Sparrows shows how destructive the House Sparrow is.

\title{
Bank Swallows Nesting in Gravel Stockpiles
}

R. W. Nero's note about Bank Swallows nesting in gravel stock-piles (Blue Jay, 19:20-21) reminds me that I saw such in a pile at the Maple River west of Fargo several years ago. In this case I think the pile happened to be undisturbed for a few years. I suspect that one reason that gravel piles are not more commonly used by swallows is that they are heterogeneous. I have often noticed that on banks swallows use tine sandy layers and avoid the more gravelly ones.o. A. Stevens, State University, Fargo, N.D.

Dr. Nero's statement that gravel piles might prove precarious sites for nesiting Bank Swallows (Ibid.) brought to memory an incident which happened in the summer of 1959. While wcrking on a railway gang near Lestock, Saskatchewan, I noticed that Bank Swallows had tunnelled into a highway gravel stock-pile located close to the railway track. I mentioned this to a fellow worker who was also interested in natural history, as he, too, had never seen this type of nesting site before. As our work progressed I wasn't able to observe the colony any further but a few days later my friend told me that while passing by the gravel pile, he actually saw a section of the pile collapse, taking the colony with it. What a sight to see-frantic parents flying in all directions, with a cloud of dust, feathers and nesting material in the air!-Bill Richards, Saskatoon. 